[J. Appl. Glycosci., Vol. 49, No. 3, p. 319-325 (2002)]

解 説

高齢者社会における段階的な拱食・曣下訓練食の開発*

\author{
渡瀬峰男
}

食品ゲル研究所（435-0028 浜松市飯田町 894-1）

\begin{abstract}
Research on Development for Diets of Patients with Dysphagia in Aged Society*
Mineo Watase
\end{abstract}

Research Institute of Food Gels (894-1, Iidacho, Hamamatsu 435-0028, Japan)

\begin{abstract}
Dynamic viscoelastic measurements and functional tests were carried out for diets of paients with dysphagia. Both storage and loss shear moduli $\mathrm{G}^{\prime}$ and $\mathrm{G}^{\prime \prime}$ for diets of paients with dysphagia were strongly frequency dependent. Frequency was changed from 0.01 to $2 \mathrm{~Hz}$. It is believed at present that a dominant factor governing the mechanics of gelation of polysaccharide gels is the balance between the hydrophilic and hydrophobic properties of the molecule of polysaccharides, or the balance between the affinity to water and the tendency toward formation of microcystalline structure in polysaccharide molecules.
\end{abstract}

わが国では, どの国よりも急速な高齢化が進行して おり, 将来は最も高龄化率の高い国になることは確実 である。また，21 世紀半ばには，先進国や発展途上 国に無関係に地球全体が高齢者社会に入るといわれて いる．高龄化が高くなると，高齢化の急速なスピード に伴って後期高齢者が急増するとみられる．後期高齢 者が急增することは, 寝たきりや痴呆になる率が高ま るため, 2025 年の要介護老人は現在の約 2.6 倍の 520 万人になると推定されている.

このような背景のなかで，すでに少子化などによる 家族の小規模化, 共働き世帯の増加, 高龄者世帯の増 加など世帯構成の急激な変化が起こってきている，厚 生労働省が発表した国民生活基礎調查によると高齢者 世帯は 626 万を突破して 25 年前の約 6 倍に増加して いる.これらは, 社会保障の重要さをさらに高める一 方, 少子化の進行に伴う現役世代の減少で, 医療や介 護負担増など種々の方面に及ほす影響は大きく, 将来 わが国にとって最も重大な制約条件となるであろう.

将来, 高齢者社会における摂食・嚥下困難者の増加 が予想される，そのため，筆者は摂食・噁下訓練食を

*本解説は平成 13 年度東日本支部シンポジウムで 講演されたものを読みやすく解説にまとめられた ものです。
以下のように四つに区別して考察する．第一に，嚥下 訓練食が生命の危険につながったり，あるいは苦痛に なったりしないこと。これらは，燕下開始食の調理・ 加工および段階的な訓練食の移行を注意することで避 けられると思われる，そのために，ゲル形成物質の しっかりとした品質管理が重要である.

第二に, 嚥下食は訓練食であること。つまり，段階 的な訓練食であり，訓練食のリハビリテーションであ ること.つまり食事に目標をもたせることは食事を楽 しくすることである.

第三に，摂食（食べること）を考慮して調理・加工 することは，常に排泄のことも同様に考えることであ る.

第四に，嚥下訓練食は咀嚼訓練食でもある．加齢と ともに歯の丧失は避けられない. 歯の喪失は咀嚼機能 を低下させる，その結果，脳に悪影響を与えるといわ れている. 従って, 咀嚼機能が低下すると, 嚥下機能 も低下するといわれている。つまり，咀嚼と嚥下は連 関しており，咀嚼が困難になれば嬹下も困難になる。 嚥下困難者は仮性球麻瘦で食品の丸吞み込みを特徵と しているが，嚥下反射（ゴクンができる）が残ってい る。この場合，嚥下開始食からスタートする，嚥下困 難者に対する嚥下開始食はほとんど咀嚼しないで, 咽 
頭内を 1 秒以内でスムーズに通過できることが不可欠 である。このような機能特性をもつ嚥下開始食の基盤 はゲル状態であり，そのゲル状態のレオロジー的性質 は厳しい条件に設定される。これらは，嚥下開始食の 品質管理をしっかりしないと, 食塊が咽頭内で詰まっ たり，気管に入るなど生命の危険につながる，そのた め，食事が苦痛になったりしないために，嚥下開始食 に対する性質の基準が厳しいことが望ましい。つま り，嚥下開始食の基準設定をしっかりすることによっ て上記の危険性が避けられ，嚥下訓練食をスムーズに 進行させることができる．

蛋白質系の豆腐, 肉, 魚製品などや炭水化物系のご 飯, めん類など，また，脂肪系のマーガリン，バター などほとんどの食品は広い意味でゲル状態といえる.

ところてん，豆腐，かまほこ，はんぺんなど日本の食 文化から多数のテクスチャー表現用語が使用されてき た。これらのゲル食品が口腔内で咀嚼され咽頭内をス ムーズに通過するためには，これらの食塊の変形や流 動の挙動を調べなくてはならない.これらを調べるた めには食塊のレオロジー的性質の研究が有効であ る $^{1-12)}$. 口腔内や咽頭内でひき起こされる感覚特性が 物理的性質であれば動的粘弾性測定によって多面的な 側面から考察される. 物理的測定の特徵は食品（ここ では嚥下食)の性質を再現よく測定できることである. これらの測定法が多面的な角度から迅速で，かつ再現 よく測定することによって，しっかりとした品質管理 が可能となる．これらを $\mathrm{X}$ 線造影検査 $(\mathrm{VF})$, 内視鏡 観察（VE）や官能検査などと平行して行うと，物理 測定との関係が明白になる。そのため，煩わしい VF, VE や官能検查をしなくとも, 必要な嚥下訓練食 を物理的測定から調理・加工することが可能である.

厳しい条件に設定されたゲル状嚥下開始食の性質は 食材の添加によって, ゲル構造が変化したり, ゲルの 均質性などが失われるおそれがあるため，ほとんどの 嚥下開始食は水分補給用に限られる。次の訓練食に移 行する準備として食材の種類および添加量がゲル構造 に与える影響を調べておく，嚥下開始食の調理・加工 が可能になったら，次に味，香り，喫食温度などを考 慮する。

食事の基本は安全で美味しいことである。そして， 掑食・曣下訓練食 (老人食) の基本は食事は楽しく, 苦痛ではないこと，さらに老人食は多種少量である. これらを追求することが, 摂食・嚥下訓練食の調理 · 加工のヒントとなる.

\section{ゲル状嚥下開始食の調理・加工に対する テクスチャーなどの必須条件}

嚥下障害が強く出現している高齢者は嚥下開始食を 始めることが可能か, 専門医によるVFやVEなどが 必要である。そ結果, 燕下開始食を始めることが可 能になると, 燕下反射を誘発するための口腔内などの 粘膜表面をアイスマッサージする ${ }^{(3)}$. そして, 段階的 な嚥下訓練食の調理・加工に入ることになる。嚥下障 害の強く出現している高齢者は嚥下に関する筋肉の運 動性の低下と筋力の低下などにより，口唇での食物の 取込みが悪かったり，食物が口唇からこほれたり，あ るいは咀嚼がうまくいかなかったりするといわれてい る.しかし，嚥下反射（ゴクンができる）が残ってい る。これらに該当する高齢者は嚥下反射の誘発が弱い ため, ほとんど咀嚼しないで嚥下する

従って, 口唇から取り入れた嚥下開始食はほとんど 咀嚼しないで奥舌に送り込まれる。 その後, 嚥下開始 食は咽頭内に送り込まれるが, 嚥下反射の誘発が弱い ため，咽頭内を 1 秒以内でスムーズに通過できるよう に調理・加工を工夫しなければならない。曣下開始食 が咽頭内を大変形をして食道に送り込まれるとき, 食 塊（嚥下開始食）がべたついたり，パサついたりする と, 咽頭に詰まったり, 気管に入り誤嚥を起こす危険 がある. 小さな応力で大变形をして食道に送り込まれ るためには, 曣下開始食が弱いゲル状態であることが 不可欠である11,2).これらのゲルは均質性であり, さ らに溶媒の水が均一に分布した状態にあり，ゲルの硬 さと軟らかさなどの值が厳しく制限される。これらは 上述した条件を満たしていることが不可欠である ${ }^{1-12}$.

さらに，咽頭内をスムーズに通過するために，食塊 の機能特性, 喫食温度と水の特異な性質など, 嚥下開 始食に与える影響が無視できないため調理・加工にお いて十分に注意する。

以上のことは, 図 1 (a)および (b)から明らかであ る。図 1 (a)では, 食塊が奥舌に送り込まれると, 嚥 下反射が誘発されて咽頭へ送り込まれる. 図 1 (b)で は, 食塊が咽頭内を全体に密着して 1 秒以内で食道に 送り込まれる。これがスムーズに行かないと，「むせ」 や「誤嚥」などが起こる，嚥下開始食が咽頭内を変形 して食道に送り込まれる場合，上述したように，これ らのレオロジー的性質（変形と流動の挙動）を調べて おくことが品質管理するうえに不可欠である ${ }^{8-12)}$. 


\section{嶼下開始食の調理・加工に 動的粘弾性測定がなぜ有効か}

燕下障害が強く出現している高齢者は食品がほとん ど咀嚼できず，嚥下反射の誘発も弱い，そのため，咽 頭内をスムーズに通過しやすい嚥下開始食を調理・加 エしなければならない，従って，曣下開始食に最適な 条件が弱いゲル状態である。この状態よりも柔らかく なると咽頭内で付着性が残り，逆に硬くなると詰まる 危険性がある1-122.

ゲル状態は固体と液体の中間の状態を意味してい る、また，ゲルは多量の液体を含有し，自重では流れ ず，型を保っている．われわれはほとんど食品をゲル 状態で撖取している，つまり，ほとんどの食品は粘弾 性体であるといえる，嚥下開始食は三次元網目構造が まだ十分に進行していない弱いゲル状態である ${ }^{1-12)}$. 例えば，ゼラチンや寒天は典型的な熱可逆性ゲルであ る．両者のゲルーゾル転移はゲルの結晶性と非晶性の 一定の均衡関係によって説明することができる ${ }^{14,15)}$.

両者の温度を上げていくと, 架橋点が切れて一定の 均衡関係は結晶性から非晶性の方向へ移動する. 即 ち, ゾルの方向へ移動する。しかし，温度を下げてい くと，分子鎖間の凝集によって架橋点が増加し，結晶 性が増大する方向に移動する（図２を参照）。また, ゲル状嚥下食は均質性, 刺激強度や咀嚼回数などに よって喠液量が変わる。これらは咀嚼などによって與 下し易い食塊形成などに影響されるが，それよりも嚥 下反射を誘発する影響の方が大きいとみられる。

しかし，嚥下開始食や次の段階の嚥下食 1 に該当す る高齢者は丸吞み込みを特徵としているため嚥下反射 の誘発が弱く咽頭内をスムーズに通過し易い性質の嚥 下食を調理・加工することや，口腔内で嚥下反射を誘 (a)

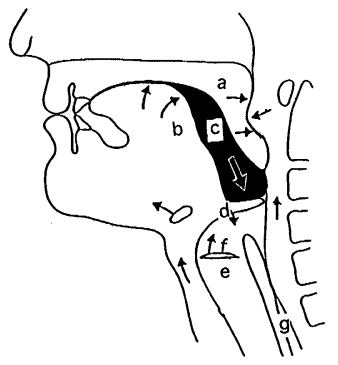

(b)

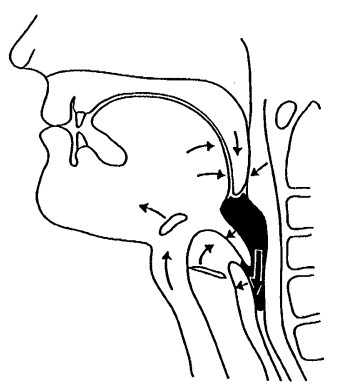

Fig. 1. Swallowing in pharynx (a) (or swallowing reflex (b)).

$a$, soft palate; $b$, tongue; c, food; d, laryngeal lid; e, windpipe; f, glottis; g, esophagus.
発し易いように工夫することが大切である。これらの 嚥下開始食および嚥下食 1 は口腔内や咽頭内の皮虚や 筋肉感覚で知覚される物理的性質が重要になる。従っ て,ゲル状態の硬さや軟らかさの割合などが定量的に 迅速で，再現性のよい測定法が必要である。

いま，嚥下開始食に周期的な外力を与えると，それ に対応する応力や変形も周期的に変化する。このと き, 変形と応力はずれて出現する. 弾性を表す基本法 則がフックの法則であり, 応力 $p$ が変形量 $e$ に正比 例する.この場合の弾性率は複素数で表現される.

$$
p=G^{*} e
$$

式(1)を実数部と虚数部にわけて表現すると

$$
G^{*}=G^{\prime}+i G^{\prime \prime}
$$

$G^{\prime \prime}$ は複素弾性率と呼ばれる. 実数部 $G^{\prime}$ はエネルギー の貯蔵に関する部分で貯蔵弾性率であり，虚数部 $G^{\prime \prime}$ は粘性によるエネルギー損失に関する部分で動的損失 である．ゲル状嚥下食中の硬い部分と軟らかな部分の 比を表すとみられる損失正接 $\tan \delta$ は $G^{\prime \prime} / G^{\prime}$ で表され る.また, $G^{\prime}$ と $\tan \delta$ の值抢よび周波数に対する勾配 から嚥下食のゾル状態およびゲル状態の性質に対する 知見が種々の側面から得られる。図3 から明らかなよ うにゾル状態からゲル状態に移動していくと $G^{\prime}$ の值 は増大していき，周波数に対する勾配が緩慢になって w<1,2).

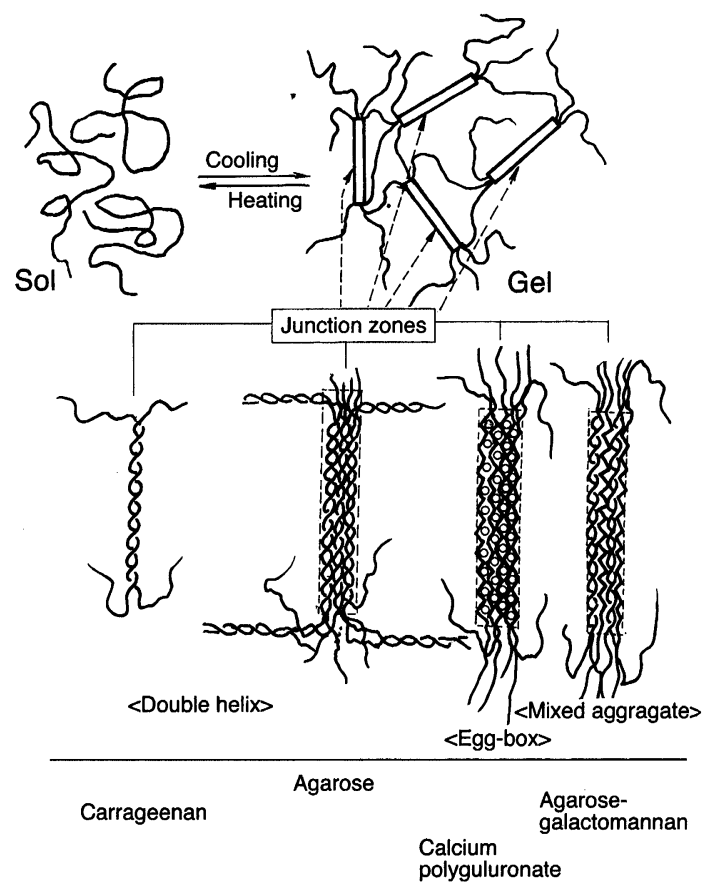

Fig. 2. Sol-gel transition of polysaccharides. 


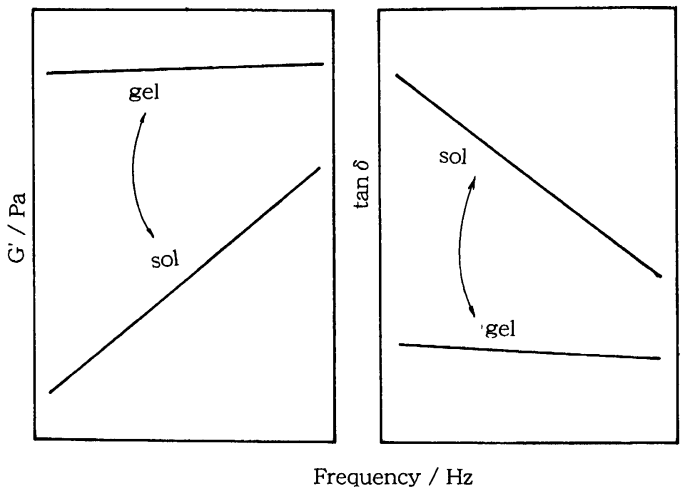

Fig. 3. Frequency dependence for storage modulus $G^{\prime}$ and loss tangent of sol-gel conditions.

一方, $\tan \delta$ の值と周波数に対する勾配は $G^{\prime}$ の場合 と逆の傾向を示す (図 3 を参照). $G^{\prime}$ および $\tan \delta の$ 值と周波数に対する勾配からゲル状態の知見が得られ $3^{1-12)}$.

これらの值はVF や VE ばかりではなく，官能試験 においても相関関係にある ${ }^{5-12}$. 動的粘弾性装置は高 価である欠点を除けば，迅速で，かつ再現性があり， 多くの知見が得られるため，嚥下訓練食の詳細な分類 に適しており，品質管理に重要である ${ }^{8-12)}$. ゲル形成 物質は天然物のため製造番号が変わると物性（レオロ ジー的性質）も変わる，そのため，品質管理が極めて 重要であるため, 徹底した品質管理をすることによ り，嚥下訓練食によって起こる生命に対する危険性の 度合いが減少する。また, 複素粘性率から動的粘性率 が求められる。これらも $G^{\prime} や \tan \delta$ と同様に考察され るが,ここでは省略する。

\section{摄食・㵰下困難者の リハビリテーションの重要性}

高齢者は加齢とともに咀嚼や嚥下などが困難になっ てくるため, 高齢化が急激に進行すると, 後期高齢者 の摂食・嚥下困難者も急増するとみられる。しかし， 後期高齢者の摂食・嚥下障害の程度は広沉におよぶた め，摂食・嚥下訓練食による段階的なリハビリテー ションが不可欠である。ここで，嚥下訓練食を以下の 順序にしたがって段階的に解説をすると，嚥下反射が 保たれているが随意的には誘発しにくい困難者が䜩下 開始食に該当する。この嚥下困難者は食事をする前に 嚥下反射を誘発するために口腔内などの粘膜表面をア イスマッサージをする.

嚥下開始食に該当する困難者の多くは食塊を「丸吞
み込み」をすることが特徴である。嬹下反射の誘発と 咀嚼は連関性があり, 嚥下反射の誘発が弱いことは, 咀嚼も同様に弱いとみられる。従って，嚥下開始食は 口腔内で咀嚼する過程で分泌される唾液はほとんど期 待できない。唾液の役割は嚥下開始食の物理的性質に 影響を与え，さらに嚥下などを容易にする．曣下開始 食は口腔内において, テクスチャーなどの知覚がほと んど期待できないため, 食塊は奥舌に送り込まれ, 嚥 下反射を誘発後, 咽頭内を 1 秒以内（コックンと吞み 込むで食道に送り込む時間）にスムーズに通過するこ とが可能なゲル状態の基盤に対する曣下開始食を調 理・加工しなければならない.この条件を満たすゲル 状態は限られており，この段階での物理的測定よる品 質管理が極めて重要である。嚥下開始食から次の段階 の嚥下食 1 に移る基準を定める。次に段階のハードル は低いほどよい。曣下開始食から嚥下食 1 への段階的 な移行がうまくいかないと咽頭内で食塊が詰まった り, あるいは食塊が誤って気管に入って「誤嚥」など になる。

これらは生命の危険につながるため十分に注意しな ければならない。この危険性は嚥下開始食から訓練食 の段階的な移行がうまくいかないために起こる確率が 高い。これらがスムーズにいかないと食事が苦痛にな り，嚥下訓練食のリハビリテーションが失敗に終った りする.

従って，これをしっかりと行えば生命の危険につな がる確率は低くなる，21 世紀は世界的に高齢者社会 を迎えるため，上記のことは乗り越えなくてはならな い.

嚥下開始食および曣下食 1 の調理・加工には，ゲル 状基盤の性質に最も注意しなければならない。そし て, 嚥下食 2 , 嚥下食 3 , 嚥下食 4 と段階的に進めて いく.また, 嚥下訓練食の段階的な移行は, 咀嚼訓 練, 摄食量の増加による栄養の改善や排泄の改善など に連関していることである (図 4 を参照).やがて, 嚥下訓練食から移行食に，そして常用食に移行してい く(図4 を参照)。さらに，これらを物性の側面からみ た場合においても，段階的な訓練につれて軟らかさ

（図4における矢印 $\mathrm{A}$ の方向）と硬さ（図 4 におけ る矢印 B の方向)が増大する方向に進む.

以上のことは，與下訓練食の種類や㩒食量の増加へ とつながるのである.

例えば，曣下開始食から嚥下食 4 における 5 段階の 訓練食を重湯ゼリーから全弱で記述すると，これらの 段階的な変化は强を粒状が残らない（ミキサー使用） 


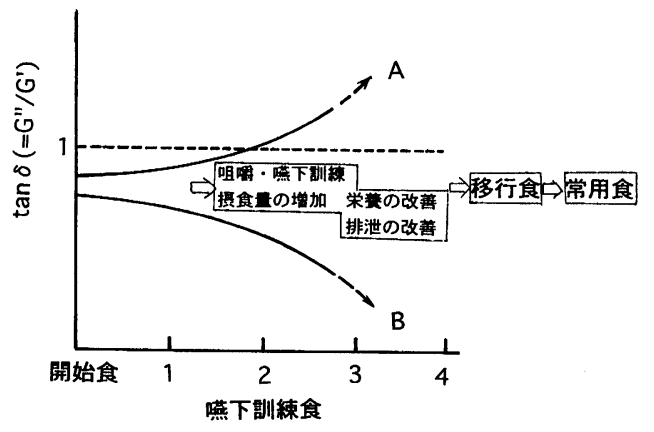

Fig. 4. Changes of loss tangent for diets of patients with dysphagia.

ように均質にするか，上新粉（酸化していない）を用 いて均質なゲルをつくる，これらとゲル形成物質の濃 度を変えて調整すると嚥下訓練食が調理・加工でき る. 次の段階的の移行は，厳しい基準を決めて慎重に 行うほど危険性は少なくなる。

以上，簡単に記述したが，筆者がこれまでに燕下訓 練食の物性の側面から取り組んで得られた結果であ る。筆者は撖食・嚥下訓練食と排泄の連関性を 3 次元 的に考察し，これを「老人食」と呼び，物性の側面から 検討している。これらの必要性は高齢者の摂食・曣下 困難者(広い意味で老人食)に対する障害の程度からみ た場合でもあまりにも広範囲におよぶからである。

現在，市販されている多くの與花下食は，軟らかであ るとか, パサつきがないとか，べたつきがないという 嚥下食が加工されている。

これらは上記の問題点を解決していない.

これらを，筆者は 1 次元的な嚥下食と呼んでいる。 さらに，嚥下訓練食は 2 次元的な嚥下食と呼んでい る. 摂食・嚥下訓練食を排泄問題と連関させて考察す ると老人食は 3 次元的に拡大していくのである.

\section{嬹下開始食の基盤に向く ゼラチンゲルの機能特性}

工業的ゼラチン製造法は酸性法とアルカリ性法があ る. 多くの場合アルカリ法ゼラチンの等イオン点 $(\mathrm{p} I)$ は $\mathrm{pH}$ 4.8-5.1 の範囲にあり, 酸性法ゼラチンの $\mathrm{p} I$ は $\mathrm{pH}$ 8.5-9.3 の範囲にある．ゼラチンを嚥下食品の基盤 に使用する場合, 添加する食材によってコアセルベー ションを起こす危険性があるため，使用する $\mathrm{p} I$ に注 意しなければならない。

ゼラチンゲルの機能特性は, (1)ゼラチンゲルは 0$15^{\circ} \mathrm{C}$ の温度範囲ではほほ一定構造を有しているが, 温度が $18^{\circ} \mathrm{C}$ に達するとゲルの内部融解が生じ, $30^{\circ} \mathrm{C}$
付近でゾルとなる ${ }^{14-20)}$. (2)ゲルを設定温度に達するま でに要する時間は他のゲルよりも長い.これらの機能 特性は口腔に取り込まれてから, 咽頭内を通過すると き，食塊の表面と内部に温度勾配が生ずる1,11,12)。こ れは嚥下をスムーズに行うための機能特性である。こ れらの状態のゼラチンゲルは複雑な咽頭内の皮厙など 全体に接し，大変形をして食道に送り込まれる。曣下 反射（ゴクンと吞み込むんで咽頭を通過する速度は僅 か 1 秒以下である) がうまくいかないと「むせ」や「誤 嚥」などが起こる。これらをスムーズにする要因は上 記のほかにゲルの硬さと軟らかさ，さらに両者のバラ ンスが重要な役割をなしている。

ゼラチンゲルが嚥下開始食に適する要因に溶媒であ る水の性質を忘れてはならない. 水は体温よりも20$25^{\circ} \mathrm{C}$ 低い温度が美味しい水の適温といわれている. 嚥下困難者はガーゼを巻いた氷水につけたアイス棒で 口腔内を刺激して摂食すると効果的であるといわれて いる. 約 $10^{\circ} \mathrm{C}$ の水の刺激効果によって，燕下反射の 誘発を起こすことが主たる要因とみられる。つまり, 嚥下開始食の喫食温度はほほ $10^{\circ} \mathrm{C}$ である

\section{嚥下訓練食に向く ゲル形成物質の構造と機能特性}

嚥下訓練食において，嚥下開始食から嚥下食 1 あた りまではゲル状の基盤に対する性質が重要である。こ れらは嚥下反射後，咽頭内をスムーズに通過させるた めに不可欠である。燕下反射にはゲル形成物質の構 造, 性質, ミネラル, 濃度や温度なども影響する。こ こでは紙面の関係で，ゼラチン，キサンタンーガラク トマンナン混合系および架橋型 $\alpha$ 化澱粉について紹 介する。

1. ゼラチン211

ゼラチンの親物質はコラーゲンである.コラーゲン のアミノ酸組成はグリシンが非常に多く全体の約 $1 / 3$ を占め，ピロリジン環をもつプロリンやヒドロキシプ ロリンが多くチロジンやメチオニンが少ない。トロポ コラーゲンの構造と性質についてはすでに明らかにさ れている．トロポコラーゲンは 3 本のポリペプチド鎖 が互いに㸚じあって，らせんをつくりポリペプチド 鎖間に水素結合が形成されている。

ゼラチンゲルはコラーゲンからの誘導たんぱく質で ある. ゼラチンゲルが鱟下開始食や嚥下食 1 の基盤に 適する条件は上述したように (a) 喫食温度がゼラチン ゲルの3次元網目構造が安定な温度範囲である。 (b)ゼラチンゲルが口腔内および咽頭内を通過すると 
き，嚥下に対して好都合の機能特性を有している，咽 頭内を通過するゼラチンゲル表面は体温によって融解 されて水の膜が形成されているため咽頭内の皮鬳表面 を滑り易くする。

さらにゼラチンゲルが大変形をして咽頭内を通過す るためには $G^{\prime}$ が約 $10 \mathrm{~Pa}, \tan \delta か ゙$ 約 $0.5\left(10-15^{\circ} \mathrm{C}\right)$ のときである。これらの值を示すゼラチンゲルは約 1-2\%である1,11,12).ささらに，ゲル中の温度勾配により 食塊が咽頭内の痰や唾液（これらは嚥下を阻害すると いわれている）を物理的に除去するとみられる。ゼラ チンゲルを嚥下開始食に使用する場合の欠点は $18^{\circ} \mathrm{C}$ 以上に長時間放置しないことである.

\section{2. キサンタンガムーガラクトマンナン混合系 ${ }^{22-24)}$}

キサンタンガム (Xan と略記) は微生物 Xanthomonas campestris により産生される多糖類である.Xanはマ ンノース，グルコース，グルクロン酸の構成糖からな り，主鎖は $\beta-1,4$ グルコシド結合からなる。側鎖は主 鎖のグルコースが一つのグルクロン酸の鎖が結合して いる．また，末端のマンノースは C 4 と C 6 の位置で ピルビン酸がアセタールで結合している．Xan 水溶液 は低濃度で弱いゲルを形成する．ゲルのレオロジー的 性質はゼラチンゲルに類似する．Xanにローカスト ビーンガム (以下 Loc と略記) を添加していくと, Loc の添加量の増加とともに, $G^{\prime}$ は増大する傾向を示す が, $\tan \delta$ は逆に減少する傾向を示す.Xan と Loc の比 が 9:1 から $7: 3$ の範囲でゼラチンゲルのレオロジー 的性質に最も類似する ${ }^{9,11,12)}$. Xan-Loc 混合水溶液ゲル の特性は加熱・冷却および凍結・解凍を反復した場 合, $G^{\prime}, \tan \delta や$ 動的粘度 $\eta^{\prime}$ などにほとんど影響しな ( $\left.{ }^{9}, 11,12\right)$ 。さらに, Xan-Loc 水溶液 (中性の状態の場合) をオートクレーブを使用して $115^{\circ} \mathrm{C} て ゙ ，$ 約 20 分間加

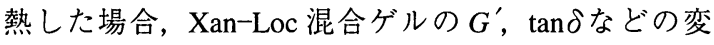
化は少ない, ${ }^{9,11,12)}$ ．以上のレオロジー的性質は嚥下訓 練食の加工に好都合の条件である。

従って，嚥下訓練食の基盤として厳しい条件の調 理・加工において，レオロジー的性質がほとんど変わ らないため, ゼラチンに代わって Xan-Loc 混合系の 使用が増加してきている，混合系中の Loc の割合が 増加してくると, $G^{\prime}$ はさらに増大し $(\tan \delta$ は減少） 寒天に類似した硬いゲルになる．混合系ゲルの特性は 濃度を一定にして，Xan と Loc の混合比を変えてレオ ロジー的性質を変えることができる（図2を参照）.

しかし，寒天とゼラチンは化学的にもレオロジー的に もかなりの差異があるため, 両者の混合系はミクロ相 分離が生じて均質なゲルを作れない（図２を参照).

\section{3. 架橋型 $\alpha$ 化澱粉 ${ }^{11,12)}$}

澱粉特有の糊化, 老化や曳系性は嚥下訓練食の調 理・加工に対して，望ましくない性質である，嚥下訓 練食の基盤に適する澱粉を以下の方法で作製した，七 ドロキシプロピル化反応とリン酸エステル架橋化反応 を組み合わせた澱粉誘導体であり，ヒドロキシプロピ ル化リン酸架橋澱粉は耐老化性, 粘度安定化処理 $\alpha$ 化 澱粉である。この澱粉は凍結・解凍の反復および加 熱・冷却の反復に対して, レオロジー的性質の影響は ほとんどみられない。

ゼラチンゲルや Xan-Loc 混合系ゲルと比較して優 れている点は冷水可溶ゲルである。これの特性は広汎 な嚥下訓練食に対する調理・加工を可能にする．例え ば，嚥下訓練食の風味を大切にする場合や迅速に嚥下 訓練食を摂取したい場合などがある。ここで，嚥下開 始食から嚥下食 4 までの嚥下訓練食としたのは，架橋 型 $\alpha$ 化澱粉とゲル形成物質の混合比や耐老化性などに 影響を与えるとみられる置換度（DS）などによって 基盤をコントロールできるからである．架橋型 $\alpha$ 化澱 粉冷水型と種々の嚥下訓練食の味および香りのバラン スは，今後の嚥下訓練食の開発に対して興味深い問題 である.

\section{圜下訓練食と品質管理}

嚥下訓練食の調理・加工において最も注意するとこ ろは，嚥下開始食と段階的な訓練食の移行である。こ れらは生命につながる危険性がある，嚥下訓練食のテ クスチャーは物理的な性質によってひき起こされる感 覚特性であることから，これらのレオロジー的性質を 再現よく測定しなければならない，迅速で，簡便かつ 再現性がよく，さらに多くの知見が得られる動的粘弾 性測定が品質管理に適していると考えられる.

\section{文献}

1 ）渡瀬峰男：嚥下障害者および高齢者に向くゲル状 嚥下食の構造と機能特性. New Food Ind., 41 (2), 71-78 (1999).

2 ) 渡瀬峰男：嚥下障害者および高齢者に向く嚥下食 の開発研究，基礎と応用 2. New Food Ind., 41 (11), 1-11 (1999).

3 ) 渡瀬峰男 : 嚥下障害者に向く食肉および魚肉の機 能特性. 食品工業, 42(23), 1-8 (1999).

4 ）渡瀬峰男：嚥下障害者の寝たきり状態から自立ま での食事からのリハビリテーション．食品工業, 43(15), 88-90 (2000).

5 ) 渡瀬峰男 : 嚥下食の基盤に適するゲル状食品の機 能特性. 食品工業, 43 (17), 74-84（2000）. 
6 ）渡瀬峰男: 3 次機能をもつ食物繊維を添加したゲ ル状嚥下食の動的粘弾性. 食品工業, 43 (19), 7484 (2000)

7 ）渡瀬峰男：嚥下障害者に向くゲル状嚥下食品の研 究 $\mathrm{Ca}^{2+}$ および $\mathrm{Mg}^{2+}$ を添加した低メトキシルメク チンゲルの動的粘弾性. 食品工業, 43 (21), 6270 (2000)

8 ）渡瀬峰男：嚥下食の基盤に向く種々の増粘多糖類 水溶液の構造と機能特性. 食品工業, $44(1), 66-$ 78 (2001).

9 ) 渡瀬峰男：ゲル形成能をもつ多糖類とキサンタン ガムーガラクトマンナン混合ゲルの動的粘弾性. 食品工業，44（5），79-93 (2001).

10）渡瀬峰男：大豆たんぱく質を添加したゲル状嚥下 食の基盤に与える動的粘弾性の影響. 食品工業, 44 (5), 71-82 (2001).

11）渡瀬峰男：嚥下困難者に向くゲル状嚥下食の基盤 に対する分類の構築．食品工業，44（11），74-85 (2001).

12）渡瀬峰男：嚥下開始食の機能特性（咀嚼・嚥下特 集). 食品工業, 44 (20), 41-49 (2001).

13）藤島一郎：「嚥下のメカニズム」, 脳卒中の捸食・ 嚥下障害 (2版), 医歯薬出版, 東京, p. 22(2000).

14) M. Watase and K. Arakawa: Rheological properties of hydrogels of agar-agar, Stress relaxation of concentrated hydrogels. Bull. Chem. Soc. Jpn., 40, 472475 (1967).

15) M. Watase: Stress relaxation of agarose gels. Bull. Chem. Soc. Jpn., 41, 1830-1834 (1968).
16）渡瀬峰男：濃厚ゼラチンゲルのレオロジー的性 質. 日化, 88, 317-320 (1967).

17）渡瀬峰男 : 尿素を添加したゼラチンゲルの応力緩 和. 日化, 90, 658-663 (1969)。

18) D.A. Ledward: Gelation of gelatin. in FunctionalProperties of Food Macromolecules, J.R. Mitchell, ed., Elsevier Appl. Sci. Pub., London, pp. 171-201 (1986).

19) M. Watase and K. Nishinari: Rheological properties of agarose-gelatin gels. Rheol. Acta, 19, 220-225 (1980).

20) M. Watase: Rheological properties of mixtures of protein. Biorheology, 20, 495-505 (1983).

21) F.A. Johnston-Banks: "Gelatin". in Food Gels, P. Harris, ed., Elsevier Appl. Sci., pp. 233-290 (1990).

22) D.A. Rees: Polysaccharide gels:A molecular view. Chem. Ind., 630 (1972).

23) G.J. Brownsey, P. Cairns, M. Miles and V.J. Morris: Evidence for intermolecular binding between xanthan and the glucomannan konjac mannan. Carbohydr. Res., 176, 329 (1988).

24) I.C.M. Dea, A.A. McKinnon and D.A. Rees:Tertiary and quaternary structure in aqueous polysaccharide systems which model cell wall cohesion; reversible changes in conformation and association of agarose, carrageenan and galactomannans. J. Mol. Biol., 68, 153 (1972).

(2001 年 11 月 12 日受付； 2001 年 11 月 27 日受理) 